\title{
PERAN TEKNOLOGI INFORMASI DALAM MENUNJANG PROSES LOGISTIK BAGI PENYELENGGARA POS DI ERA DIGITAL (KASUS DI BATAM, SEMARANG, JAKARTA DAN MATARAM)
}

\author{
THE ROLE OF INFORMATION TECHNOLOGY IN SUPPORTING \\ LOGISTIC PROCESS FOR POSTAL OPERATOR IN DIGITAL ERA \\ (CASE: BATAM, SEMARANG, JAKARTA, AND MATARAM)
}

\author{
Vidyantina H. Anandhita ${ }^{1}$ Agung Rahmat Dwiardi ${ }^{2}$ \\ ${ }^{12}$ Puslitbang SDPPPI, Badan Litbang SDM, Kementerian Komunikasi dan Informatika \\ Jalan Medan Merdeka Barat No. 9, Jakarta Pusat 10110 \\ vidy001@kominfo.go.id.
}

\begin{abstract}
Abstrak
Perkembangan perdagangan elektronik (e-commerce) berdampak pada potensi peningkatan ekonomi bagi penyelenggara pos dan logistik melalui distribusi pengiriman barang. Untuk menunjang percepatan e-commerce pada sektor pos dan logistik, maka diperlukan gambaran kondisi peran TI dalam perusahaan. Gambaran tersebut dapat memberi informasi awal bagaimana implementasi TI yang dilakukan di perusahaan penyelenggara pos memberikan dampak terhadap daya saing dan keunggulan perusahaan di era e-commerce. Penelitian ini dilakukan melalui pendekatan kualitatif dan kuantitatif dengan survei maupun wawancara kepada perwakilan high level manajerial pada 19 perusahaan yang memiliki ijin penyelenggaraan pos di 4 kota besar di Indonesia yaitu Kota Batam, Jakarta, Semarang dan Makasar. Analisis data dilakukan secara deskriptif dengan melakukan pemetaan dalam IT Strategic Impact Grid berdasarkan karakteristik TI masing-masing perusahaan. Kurangnya e-leadership dan keterbatasan investasi TI merupakan hambatan utama bagi perusahaan pos dan logistik untuk dapat menginplementasikan TI bagi perusahaan. Strategi yang diusulkan terkait peningkatan kapasitas TI perusahaan pos dan logistik untuk dapat berkontribusi pada potensi pasar e-commerce di Indonesia yaitu dengan membangun e-leadership, pemanfaatkan plaform sistem operasi virtual bersama untuk mengatasi hambatan investasi teknologi, serta peningkatan kapasitas SDM TIK.
\end{abstract}

Kata kunci: penyelenggara pos, IT Strategic Impact

\begin{abstract}
Electronic commerce (e-commerce) developments has an impact on the potential for economic improvement for postal and logistics providers through the distribution of goods delivery. To support e-commerce acceleration in the post and logistics sector, it is necessary to describe the condition of the role of IT in the company. The description can provide preliminary information on how IT implementation carried out in postal provider companies has an impact on the competitiveness and excellence of companies in the era of e-commerce. This research was conducted through qualitative and quantitative approaches with surveys and interviews to high level managerial representative respondents in 19 companies that had postal operating licenses in 4 major cities in Indonesia, namely Batam, Jakarta, Semarang and Makassar. Data analysis was carried out descriptively by mapping the IT Strategic Impact Grid based on the IT characteristics of each company. Lack of e-leadership and limited IT investment are the main obstacles for postal and logistics companies to be able to implement IT for companies. The proposed strategy is related to increasing the company's IT post and logistics capacity to be able to contribute to the e-commerce market potential in Indonesia, namely by building e-leadership, utilizing the shared virtual operating system ceiling to overcome technological investment barriers, and increasing the capacity of ICT human resources.
\end{abstract}




\section{PENDAHULUAN}

Peran sektor logistik untuk mendorong percepatan dan pengembangan sistem perdagangan nasional berbasis elektronik telah dijabarkan dalam Peraturan Presiden Nomor 74 tahun 2017 tentang peta jalan sistem perdagangan masional berbasis elektronik (roadmap e-commerce) tahun 2017-2019. Layanan logistik di Indonesia tercakup dalam UU no 38 tahun 2009 tentang Pos yang menjabarkan Pos adalah layanan komunikasi tertulis dan/atau surat elektronik, layanan paket, layanan logistik, layanan transaksi keuangan, dan layanan keagenan pos untuk kepentingan umum. Sesuai data perijinan penyelenggara pos pada tahun 2017 di Indonesia terdaftar 451 perusahaan yang mempunyai ijin penyelenggaraan pos. Di mana diharapkan penyedia jasa pos ini dapat meningkatkan kapasitas penyedia jasa logistik untuk dapat mendukung pertumbuhan ekonomi dari e-commerce.

Untuk dapat meningkatkan kinerja bisnis $e$ commerce, perusahaan perlu menggunakan pendekatan sistem manajemen logistik untuk mendukung bisnis intinya. Pertumbuhan ecommerce yang sangat cepat memberikan peluang bagi perusahaan yang bergerak di bisnis ecommerce untuk melakukan kolaborasi dengan perusahaan penyedia jasa logsitik (3PL) untuk bersama memberikan solusi permasalahan permasalahan pengelolaan logistik e-commerce untuk mencapai sasaran service level objective (SLO) dari aspek: quality, cost, dan time (Zaroni, 2015).

Hasil survei yang dilakukan oleh Evangelista dan Sweeney (2009) pada perusahaan penyelenggara logistik skala kecil di Italia menunjukkan bahwa penggunaan TIK yang relatif canggih lebih umum di penyedia yang lebih maju. Hal ini terutama terjadi dalam kaitannya dengan tingkat integrasi information system dan pertukaran informasi dengan peserta rantai pasokan lainnya. Berbagai kegiatan logistik dan teknologi yang berkontribusi pada optimalisasi rantai supply chain antara lain dalam supply management, warehouse management, stock management, order management dan distribution. (Espinosa \& Morales, 2015)

Perusahaan dengan skala besar dan maju, umumnya telah menerapkan aplikasi dan sistem informasi terintegrasi untuk menunjang rantai supply chain tersebut, sedangkan perusahaan skala menengah dan kecil umumnya masih menggunakan TIK sebagai proses otomasi dari proses manual serta sistem informasi pendukung supply chain yang belum terintegrasi dengan pemasok lainnya. Teknologi informasi dan komunikasi (TIK) menjadi sangat penting bagi pengelolaan arus antar mitra rantai pasokan, dengan memungkinkan integrasi, sinkronisasi, visibilitas, dan daya tanggap (Luisa dos Santos Vieira, Sérgio Coelho, \& Mendes Luna, 2013). Investasi TI yang dilakukan oleh perusahaan pada tahap yang paling awal sebagai otomasi proses bisnis.

Peran TI dalam perusahaan sangat bergantung pada fungsi TI yang diterapkan oleh perusahaan tersebut. Fungsi TI bagi penyelenggara logistic dalam mendukung bisnis e-commerce saat ini bukan hanya untuk proses yang bersifat otomasi tetapi juga bernilai strategis bagi perusahaannya. Munculnya inovasi baru juga dapat ditunjukan melalui hadirnya TI bagi perusahaan. Kebijakan strategis yang tepat dapat pula dihasilkan melalui intevensi antara manajemen dengan pengelolaan TI yang baik. Dengan demikian maka daya saing 
perusahaan akan bertambah dan mampu adopsi dan implementasi TIK di perusahaan logistik mengintegrasikan teknologinya dengan platform e- Indonesia dari sisi pengguna, teknologi, dan commerce. Pane (2016) telah memetakan hambatan kebijakan dalam tabel 1 berikut.

Tabel 1. Hambatan adopsi dan implementasi aplikasi TIK dari tiga segi yang terkait

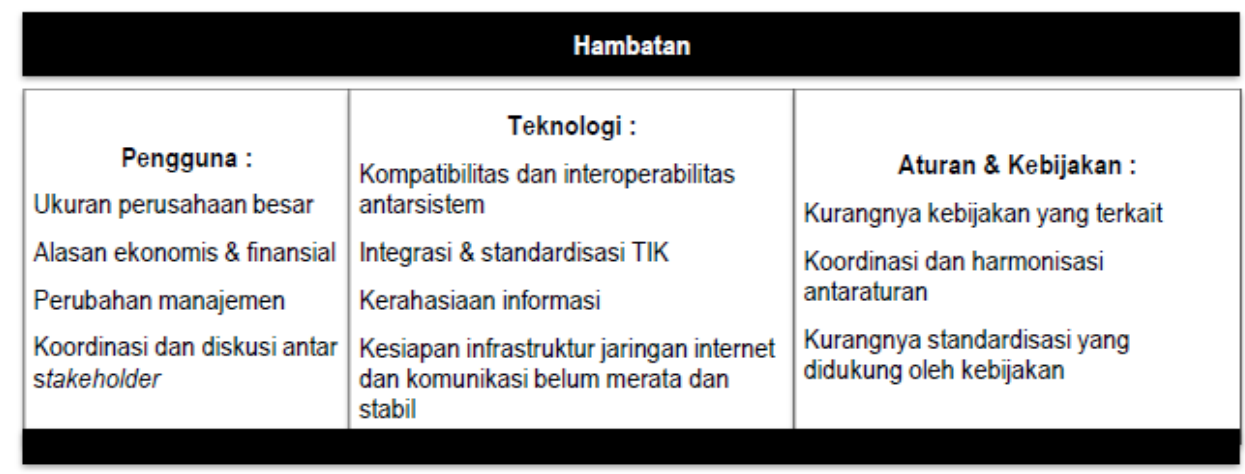

Sumber: Pane (2016)

Berdasarkan penelitian Pane (2016) di perusahaan logistik untuk menunjang proses hambatan adopsi dan implementasi TIK dari sisi bisnis. Dari gambaran peran strategis TI di beberapa teknologi antara lain kompatibilitas dan interoperabilitas antar system, integrasi, kerahasiaan informasi dan kesiapan infrastruktur jaringan internet dan komunikasi belum merata. Hambatan adopsi dan implementasi aplikasi TIK pada perusahaan logistic yang didefinisikan merupakan hambatan yang bersifat internal dan eksternal. Untuk memperkuat sektor pos dan logistik dalam pemanfaatan e-commerce di era digital, diperlukan gambaran kondisi internal pemanfaatan dan adopsi TI dalam perusahaan penyelenggara pos.

Oleh karena itu dalam penelitian ini berusaha untuk menampilkan gambaran mengenai pemanfaatan dan peran TI dalam perusahaan penyelenggara pos dan logistic. Gambaran tersebut memperlihatkan bagaimana investasi TI yang dilakukan oleh high level manajerial di perusahaan penyelenggara pos dapat memberikan dampak pada kinerja perusahaan secara keseluruhan di Indonesia. Daya saing perusahaan logistik dalam era ecommerce sangat terkait dengan peran strategis TI perusahaan logistik tersebut maka dapat diajukan rekomendasi dan strategi yang dibutuhkan untuk peningkatan daya saing TI bagi perusahaan penyelenggar pos sehingga dapat membuka peluang bisnis terkait semakin meningkatnya pertumbuhan sektor e-commerce.

Berdasarkan uraian tersebut, maka pertanyaan penelitian ini bagaimana peran TI bagi perusahaan Penyelenggara Pos dalam menunjang proses logistik di era digital e-commerce serta penerapan strategi untuk memaksimalkan potensi pasar e-commerce melalui peningkatan daya saing TI. Penelitian ini bertujuan untuk mengetahui penggunaan TI untuk mendukung proses bisnis utama logistik, bagaimana perusahaan menggunakan TI sebagai strategi untuk mendukung perusahaannya serta strategi yang diperlukan untuk meningkatkan implementasi dan adopsi TI bagi perusahaan penyelenggara logistik. 


\section{Definisi Teknologi Informasi}

Revenaugh (1994) dalam (Jafari, 2014) menyebutkan pentingnya TI dalam organisasi beragam tergantung dari seberapa kritikal TI atau aplikasi SI untuk mencapai strategic goal secara keseluruhan. (Nolan \& McFarlan, 2005) menentukan keterlibatan dewan direksi (atau pimpinan perusahaan) dalam dua isu strategis: pertama adalah seberapa besar perusahaan mengandalkan sistem teknologi operasi yang hemat biaya, tidak terganggu, aman, lancar (disebut sebagai "defensif" TI) dan kedua adalah seberapa besar perusahaan mengandalkan TI untuk keunggulan kompetitifnya melalui sistem yang memberikan layanan dan produk bernilai tambah baru atau responsif tinggi kepada pelanggan ("ofensif" TI).

\section{IT Strategic Impact Grid}

Salah satu metodologi evaluasi TI dalam arah strategis perusahaan adalah IT Strategic Impact
Grid yang dikembangkan oleh McFarlan et al. (1983) dan dijabarkan kembali oleh Nolan dan McFarlan (2005). IT Strategic Impact Grid membagi perusahaan dalam 4 mode yang terkait dengan bagaimana kebijakan dari pemimpin perusahaan/direksi memposisikan TI dalam perusahaan. Perusahaan dalam mode Support paling tidak bergantung pada TI; sedangkan yang berada dalam mode Factory jauh lebih bergantung pada TI namun relatif tidak ambisius dalam hal penggunaan strategi, perusahaan dalam mode Turn Around mengharapkan bahwa sistem baru akan mengubah bisnis mereka; sedangkan dalam mode Strategic memerlukan sistem yang andal dan teknologi yang berkembang untuk mempertahankan atau memajukan posisi kompetitif mereka (Nolan \& McFarlan, 2005)

Tabel 2. IT Strategic Impact Grid

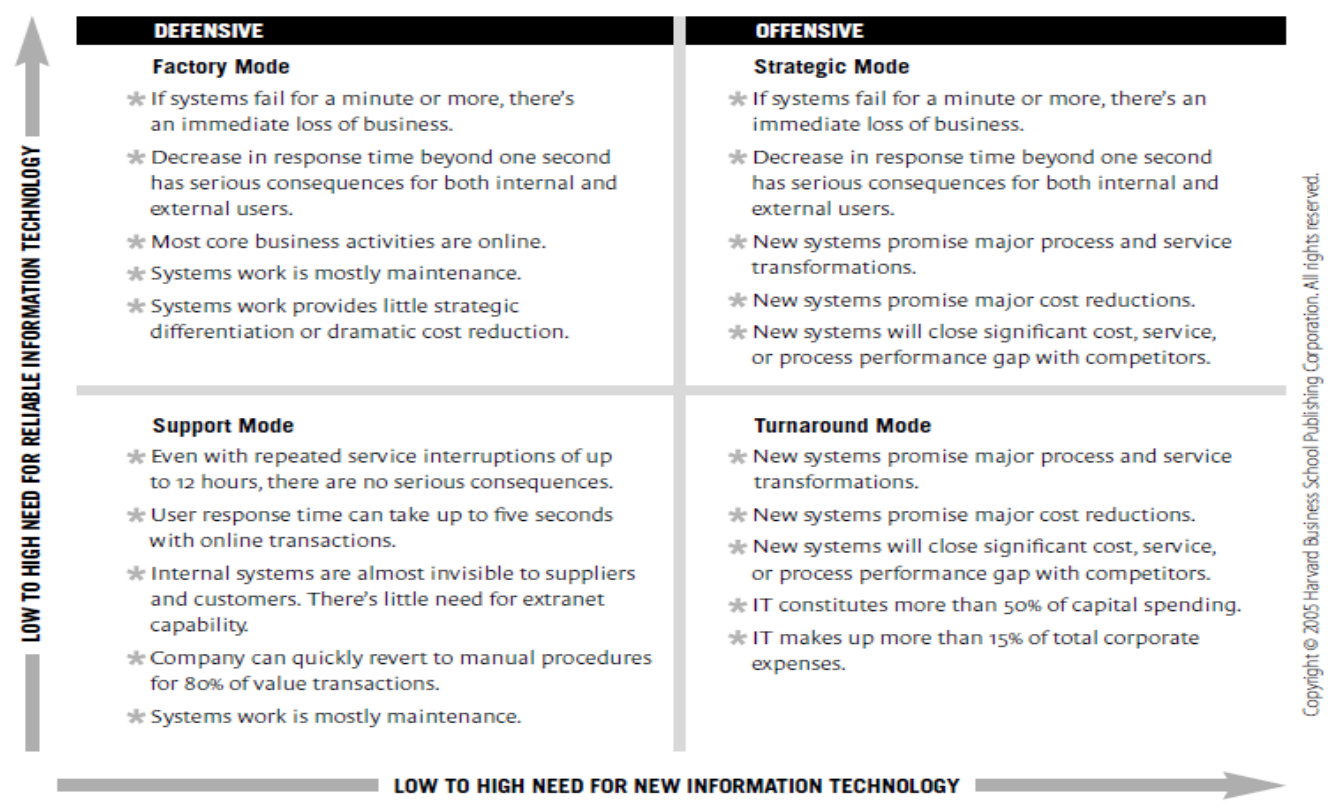


Berdasarkan tabel 2, penjelasan setiap mode dalam empat mode strategic impact grid oleh Nolan dan McFarlan (2005) adalah sebagai berikut:

\section{Mode Support (Defensive)}

Perusahaan memiliki kebutuhan keandalan dan kebutuhan strategis TI yang relatif rendah; teknologi secara fundamental digunakan untuk mendukung kegiatan karyawan. Sistem bisnis inti biasa dijalankan dalam sejumlah siklus yaitu sebagian besar koreksi kesalahan dan backup dilakukan secara manual. Pelanggan dan pemasok tidak memiliki akses ke sistem internal. Perusahaan dalam mode Support dapat mengalami gangguan layanan berulang hingga 12 jam tanpa konsekuensi yang serius, dan waktu respons Internet berkecepatan tinggi tidak penting.

\section{Mode Factory (Defensive).}

Perusahaan dalam mode ini membutuhkan sistem yang sangat andal dan bergantung pada kelancaran penerapan teknologinya, karena sebagian besar sistem bisnis inti mereka online. Perusahaan akan mengalami kerugian segera jika sistem gagal bahkan semenit pun; pengembalian ke prosedur manual itu sulit,. Perusahaan mode Factory umumnya bergantung pada ekstranet mereka untuk berkomunikasi dengan pelanggan dan pemasok. Biasanya, organisasi mode pabrik tidak tertarik untuk menjadi yang pertama menerapkan teknologi baru, namun manajemen dan direksi puncaknya perlu menyadari praktik terdepan dan memantau lanskap kompetitif untuk setiap perubahan yang memerlukan penggunaan yang lebih agresif.

\section{Mode Turnaround (Ofensive).}

Perusahaan pada mode di tengah transformasi strategis, biasanya teknologi menyumbang lebih dari $50 \%$ pengeluaran barang modal dan lebih dari $15 \%$ biaya perusahaan. Sistem baru menjanjikan perbaikan proses dan layanan utama, pengurangan biaya, dan keunggulan kompetitif. Pada saat yang sama, perusahaanperusahaan dalam mode ini memiliki kebutuhan keandalan yang relatif rendah dan seperti perusahaan dalam mode Support, dan aktivitas bisnis utama tetap dalam siklus batch. Setelah sistem baru dipasang, sistem manual digantikan prosedur dengan sistem dan database. Sebagian besar perusahaan tidak menghabiskan waktu lama dalam mode turnaround, begitu perubahan itu dilakukan, mereka bergerak ke mode Factory atau mode Strategic.

\section{Mode Strategic (Ofensive).}

Bagi beberapa perusahaan binisnya ditopang oleh total inovasi. Teknologi baru tidak hanya cara untuk mendekati pasar tetapi juga cara menjalankan operasi sehari-hari. Perusahaan mode strategis membutuhkan keandalan sebanyak yang dilakukan oleh perusahaan mode Factory, namun mereka juga secara agresif mengejar peluang proses dan layanan, pengurangan biaya, dan keunggulan kompetitif. Seperti perusahaan Turnaround, pengeluaran TI mereka besar. Beberapa perusahaan mengambil mode ini karena menghadapi persaingan dengan tekanan kompetitif.

\section{METODE}

Penelitian ini dilakukan melalui survei dan wawancara kepada perwakilan perusahaan yang memiliki wewenang dalam menetapkan strategi TI pada 19 perusahaan yang memiliki ijin penyelenggaraan pos di 4 kota besar di Indonesia yaitu Kota Batam, Jakarta, Semarang dan Makasar. Perusahaan dipilih berdasarkan data perusahaan 
yang memiliki ijin penyelenggaraan Pos dari Direktorat Pos, Dirjen Penyelenggaraan Pos dan Informatika Kementerian Kominfo. Responden dipilih di kota tersebut untuk melihat gambaran perusahaan di wilayah Indonesia Barat dan Tengah, dimana penetrasi transaksi e-commerce masih terkonsentrasi di wilayah tersebut.

Alur pelaksanaan dalam penelitian ini dapat digambarkan sebagai berikut

1. Melakukan pengumpulan data primer melalui wawancara kepada high level manajerial perusahaan penyelanggara logistik di kota Batam, Semarang, Jakarta dan Mataram.

2. Melakukan pemetaan terhadap responden (perusahaan) ke dalam IT Strategic Impact Grid

Berdasarkan hasil pemetaan, dilakukan perumusan strategi untuk peningkatan daya saing TI perusahaan

pos.

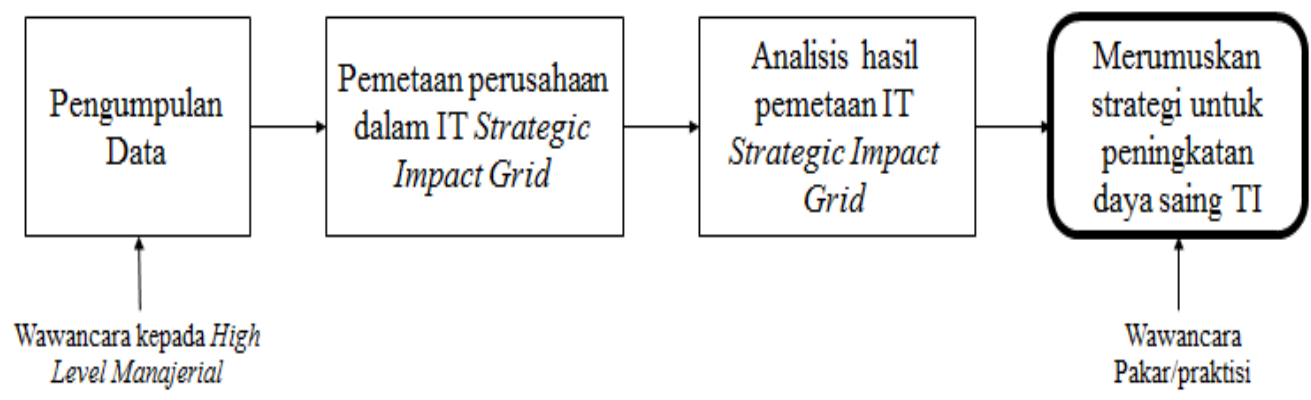

Gambar 2. Alur Pelaksanaan Penelitian

\section{Pengumpulan data}

Pengumpulan data melalui wawancara terstruktur untuk menggali bagaimana TI mempengaruhi proses bisnis di perusahaan, aplikasi yang digunakan, ketersediaan SDM TI, inovasi TI untuk keunggulan kompetitif, dan biaya untuk investasi atau maintenance TI di perusahaan. Narasumber dalam penelitian ini merupakan high level manajerial yang memiliki kewenangan dalam menentukan investasi dan penerapan TI dalam perusahaan, diantaranya direktur utama, ataupun wakil direktur. Daftar narasumber dan karakteristik perusahaan dapat dilihat pada lampiran (1).

\section{Pemetaan IT Strategic Impact Grid}

Hasil survei serta transkrip dari wawancara kepada responden, diolah untuk mendapatkan profil perusahaan serta kemudian menjadi data untuk memetakan masing-masing perusahaan ke dalam IT Strategic Impact Grid dengan memperhatikan aplikasi yang digunakan oleh perusahaan, fungsi dari masing-masing aplikasi, penggunaan TI dalam perusahaan, pola pemeliharaan TI, investasi serta inovasi terkait pengembangan TI.

\section{Analisis dan Perumusan Strategi}

Hasil pemetaan dalam tabel IT Strategic Impact Grid dilakukan dengan analisis deskriptif untuk menjelaskan kondisi khas dari penggunaan TI di perusahaan yang menjadi responden. Wawancara kepada perwakilan Asperindo dilakukan untuk merumuskan strategi peningkatan daya saing TI bagi perusahaan penyelenggara pos. 


\section{HASIL DAN PEMBAHASAN}

Perusahaan penyelenggara pos dan logistik rata-rata merupakan perusahaan kecil. Pada umumnya perusahaan kecil terbatas pada sumber daya sehingga manfaat investasi dalam TIK modern perlu dipahami dan dicapai secara jelas, misalnya pelacakan dan penelusuran pengiriman, karena melalui perangkat TIK berpotensi untuk memperbesar jangkauan layanan yang ditawarkan oleh penyedia layanan logistik kecil (Evangelista \& Kilpala, 2007). Akan tetapi penelitian yang dilakukan oleh Evangelista dan Kilpala di Eropa (2007) menyatakan bahwa keuntungan dari penggunaan TIK ini dicapai jika perusahaanperusahaan ini dapat mengatasi hambatan investasi teknologi. Di Indonesia, investasi TIK juga menjadi kendala utama bagi perusahaan kecil menengah dengan modal yang terbatas.

Karakteristik perusahaan penyelenggara pos dan logistik di Indonesia mayoritas memiliki tipe layanan LSP (Basic Services) sebanyak 65\% (“Logistic Summit 2015", 2015), yang didominasi perusahaan kecil dan menengah, di mana setiap perusahaan dengan tipe layanan ini hanya berfokus pada aktivitas layanan logistik tertentu, misalnya: pergudangan, jasa kurir, transportasi, atau Freight Forwarding. Pada penelitian yang dilakukan mayoritas perusahaan yang menjadi responden merupakan perusahan penyelenggara pos dan logistik dengan basic service terutama berfokus pada layanan jasa kurir/ paket dan logistik.

Asosiasi Perusahaan Jasa Pengiriman Ekspres Pos dan Logistik (Asperindo) Indonesia menyatakan potensi bisnis kurir (pos) dan logistik meningkat dengan semakin pesatnya e-commerce, potensi pertumbuhan bisnis jasa kurir dan logistik dapat mencapai $30 \%^{1}$. Karenanya untuk dapat berdaya saing memperebutkan potensi pasar dari perkembangan e-commerce, perusahaan pos dan logistik dituntut untuk dapat memanfaatkan teknologi informasi yang menunjang kebutuhan konsumen dari e-commerce.

\section{Hasil Wawancara dan Observasi}

Berdasarkan hasil wawancara dan observasi, profil perusahaan yang menjadi responden penelitian terutama terkait sistem informasi yang dimiliki dan sejauh mana penggunaan TI dalam perusahaan dibahas pada kepemilikan website perusahaan, penggunaan data elektronik interchange (EDI), penggunaan barcode, kepemilikan sistem informasi yang terintegrasi serta training bagi SDM TIK. Data profil perusahaan responden tersebut dijabarkan sebagai berikut:

\section{a. Biaya operasional perusahaan dan kepemilikan website}

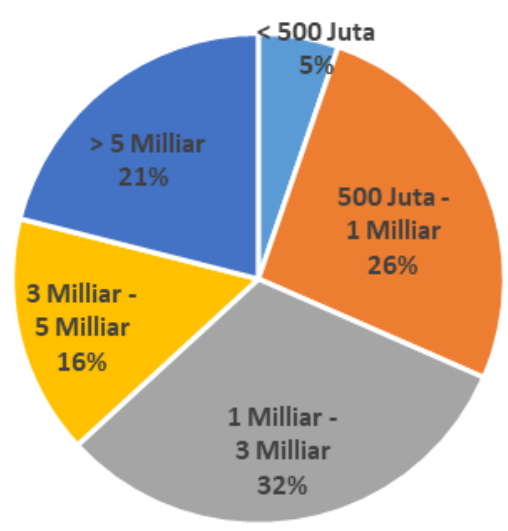

Gambar 3. Biaya Operasional Perusahaan per Tahun Sumber: Hasil Penelitian, 2017

\footnotetext{
${ }^{1}$ https://bisnis.tempo.co/read/1038571/e-commercedongkrak-pertumbuhan-industri-logistik-30-persen
} 


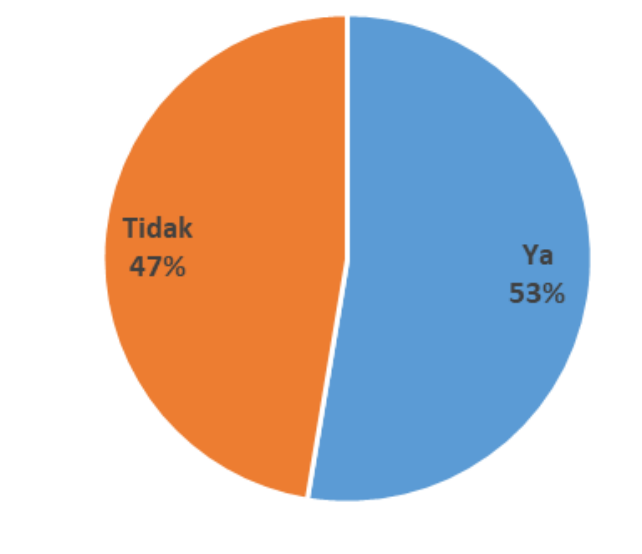

Gambar 4. Kepemilikan Website

Mayoritas perusahaan yang menjadi obyek penelitian merupakan perusahaan pelayanan basic service dengan skala kecil dan menengah, hanya $21 \%$ perusahaan mempunyai biaya operasional lebih dari 5 M Rupiah per tahun. Sebagian perusahaan masih melaksanakan proses bisnis tradisional yang berlandaskan kepercayaan dan kemitraan antar pelanggan, sehingga kebutuhan perusahaan untuk memiliki website belum terlalu dipentingkan. Sebesar $47 \%$ perusahaan yang menjadi responden belum memiliki website.

\section{b. Penggunaan electronic data interchange (EDI)}

EDI merupakan sistem yang memungkinkan perusahaan untuk saling mempertukarkan informasi terkait bisnis baik di lingkup internal maupun eksternal perusahaan. Data dan informasi yang dipertukarkan melalui sistem EDI menggunakan standar format tertentu sehingga infromasi tersebut dapat saling dipahami oleh pihak-pihak yang mengunakan sistem EDI. Sistem EDI terdiri atas tiga lapisan (layer) yang meliputi Communication layer, Syntax Layer, dan Message Layer. Berdasarkan hasil survei didapatkan hasil bahwa 79\% responden menyatakan bahwa komputer tidak terhubung ke pelanggan atau pemasok secara elektronik. Dalam sebuah studi yang menyelidiki adopsi EDI di dalam suatu perusahaan diperlukan tingkat penetrasi yang tinggi untuk membuat EDI sukses, dan penetrasi mungkin terhambat oleh penolakan perusahaan kecil untuk menerima EDI (Naicker \& Pillay, 2010).

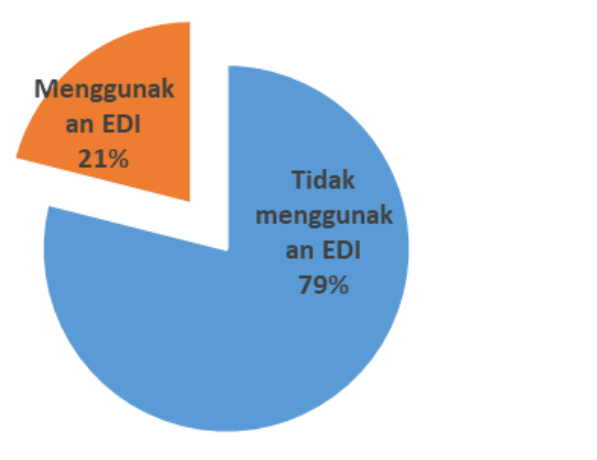

Gambar 5. Kepemilikan EDI

Sumber: Hasil Penelitian, 2017

Perusahaan yang menjadi responden dalam penelitian ini memang didominasi oleh perusahaan kecil dan menengah, sehingga penetrasi TIK cukup rendah terhadap perusahaan ini. Meskipun EDI memiliki peran yang cukup penting bagi kemajuan perusahaan namun masih banyak penyelenggara yang tidak menggunakan teknologi ini. Pertukaran data lintas perusahaan dilakukan dengan cara manual karena belum ada platform yang dibangun untuk melakukan hal tersebut. Tidak banyak perusahaan yang sudah menggunakan EDI sebagai tools untuk melakukan pertukaran data. Bisa dikatakan perusahaan yang menggunakan EDI umumnya adalah perusahaan yang memiliki modal besar dengan jaringan yang cukup luas.

\section{c. Penggunaan barcode}

Teknologi barcode membantu dalam mengintegrasikan pengelolaan kegiatan logistik meliputi pembelian barang, penjualan hingga penyimpanan barang (Hong-Ying, 2009). Teknologi ini memudahkan dalam inventarisir barang, meminimalisir database entry secara manual, mengurangi tingkat kesalahan dalam identifikasi 
barang, pengumpulan data barang secara real time, dan efisiensi biaya.
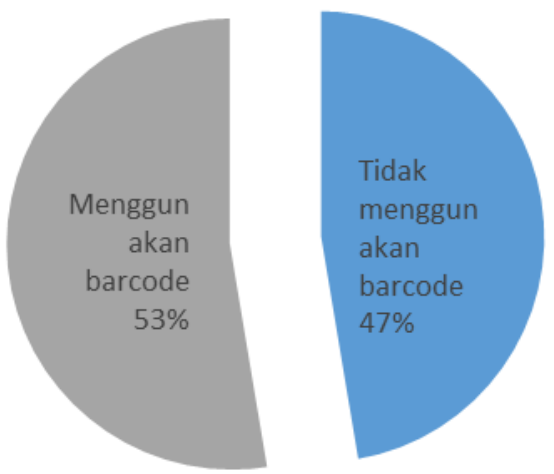

Sumber: Hasil Penelitian, 2017

Gambar 6. Penggunaan Barcode

Penggunaan barcode bagi perusahaan yang berlokasi di kota sudah merupakan suatu keharusan. Perusahaan di kota besar umumnya mendapatkan load pengiriman paket/barang yang relatif lebih banyak. Oleh karena itu untuk memangkas waktu operasional dalam hal pencatatan kode barang kiriman dan inventarisir data lain diperlukan penggunaan teknologi barcode. Namun masih cukup banyak pula (53\%) perusahaan yang tidak menggunakan teknologi barcode ini. Temuan di lapangan mengatakan bahwa banyak perusahaan di luar Jakarta yang masih menggunakan cara konvensional dengan mencatat kode disetiap paket kiriman. Perusahaan -perusahaan yang masih menggunakan cara ini umumnya merupakan perusahaan yang sudah lama beroperasi, perusahaan dikelola oleh pengurus yang kurang menguasai perkembangan teknologi dan belum ada regenerasi di struktur organisasi perusahaan tersebut. Walaupun dengan cara konvensional perusahaan merasa masih mampu melayani pelanggan.

\section{d. Kepemilikan sistem informasi terintegrasi}

Sistem yang terintegrasi baik secara internal perusahaan maupun ekternal dalam logistik untuk menunjang supply chain management (SCM). Simchi-Levi et al (1999) dalam (Mulyadi, 2011)) mengemukakan bahwa SCM merupakan pendekatan yang diterapkan untuk mengintegrasikan suplier, pengusaha, gudang dan tempat penyimpanan lain secara efisien sehingga produk yang dihasilkan dan didistribusikan dengan kuantitas yang tepat, lokasi yang tepat dan waktu yang tepat untuk memperkecil biaya dan memuaskan kebutuhan pelanggan

Melalui penerapan konsep SCM yang terintegrasi dalam perusahaan akan memberikan manfaat yaitu kepuasan pelanggan, meningkatkan pendapatan, menurunnya biaya, pemanfaatan asset yang semakin tinggi, peningkatan laba, dan perusahaan semakin besar (Jebarus, 2001 dalam (Widyarto, 2012).

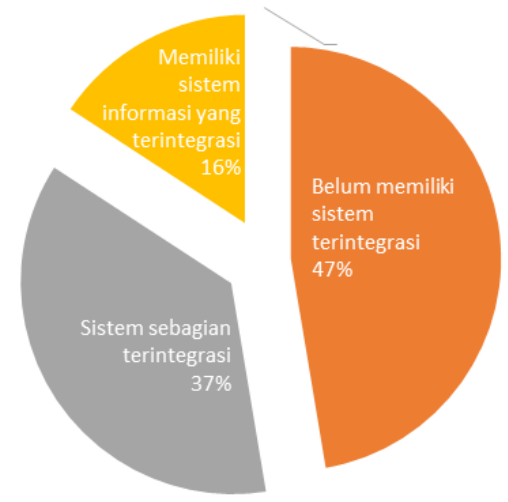

Gambar 7. Penggunaan SI terintegrasi Sumber: Hasil Penelitian, 2017

Perusahaan responden yang memiliki system informasi terintegrasi hanya sebagian kecil (16\%), sementara $37 \%$ memiliki SI sebagian telah terintegrasi, sedangkan $47 \%$ perusahaan belum memiliki system yang terintegrasi. 


\section{e. Kompetensi TI Bagi Karyawan}

Kompetensi merupakan salah satu asset intangibile yang harus dimiliki oleh suatu perusahaan. Saat ini industri di global telah memasuki revolusi industry ke-4 dimana teknologi memiliki peranan yang sangat penting untuk memenangkan persaingan industry di lingkup global. Di negara berkembang, orang dengan pendidikan tinggi akan mendapatkan keutungan lebih dari pendidikannya, terutama pada pekerjaan yang membutuhkan penggunaan TIK, selain itu yang lain mencari pekerjaan dengan keterampilan rendah, misalnya dalam pemeliharaan konstruksi dan layanan hotel (Ilich, 2017). Permintaan akan layanan semacam itu akan terus berkembang namun tidak cukup memadai untuk mempertahankan tingkat gaji sebelumnya (World Development Report 2016 “Digital Dividends,” 2016)

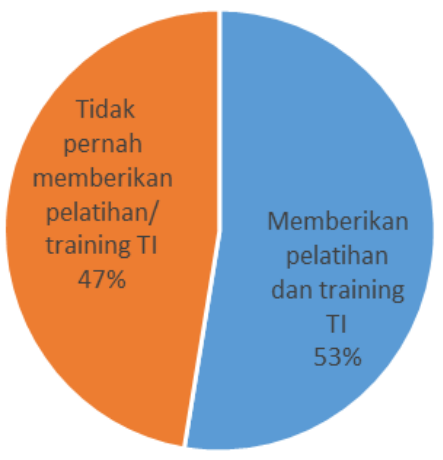

Gambar 8. Pelatihan/Training TI

Sumber: Hasil Penelitian, 2017
Dalam penelitian ini sebanyak 53\% perusahaan sudah memiliki inisiatif untuk memberikan pelatihan di bidang IT. Pelatihan ini ditujukan guna untuk meningkatkan kemampuan karyawan dalam pengelolaan teknis TIK misalnya peningkatkan kemampuan networking infrastructure, web programming, pengelolaan data. Walaupun TI bukan merupakan core dalam bisnis ini namun setiap perusahaan berupaya untuk mengikuti perkembangan kebutuhan industri. Hal ini dapat dilihat dari perusahaan - perusahaan yang mulai melakukan perubahan di lini perusahaan misalnya penambahan divisi TI dalam struktur organisasi perusahaan, melakukan strategi pemasaran yang bersifat digital, membangun sistem pengiriman pelacakan barang dan sebagainya.

\section{HASIL DAN PEMBAHASAN}

\section{Pemetaan Dalam IT Strategic Impact Grid}

Berdasarkan hasil wawancara yang dilakukan terhadap high level manajerial perusahaan penyelenggara pos dan logistik di empat kota di Indonesia yaitu Batam, Jakarta, Semarang dan Makasar, maka dapat dipetakan ke dalam karakteristik dampak TI terhadap perusahaan berdasarkan IT Strategic Impact Grid. Hasil pemetaan dapat dilihat pada tabel berikut:

Tabel 3. Pemetaan Perusahaan berdasarkan IT Strategic Impact Grid

\begin{tabular}{|c|c|c|c|c|}
\hline Perusahaan & $\begin{array}{c}\text { Biaya } \\
\text { operasional } \\
\text { per tahun }\end{array}$ & Karakteristik & Jenis Layanan & Mode \\
\hline Batam A & 500Juta-1M & $\mathrm{B} 2 \mathrm{~B}, \mathrm{~B} 2 \mathrm{C}$ & $\begin{array}{l}\text { Komunikasi Tertulis/ Surat } \\
\text { Elektronik, Paket }\end{array}$ & Support \\
\hline Batam B & $>1 \mathrm{M}-3 \mathrm{M}$ & $\mathrm{B} 2 \mathrm{~B}, \mathrm{~B} 2 \mathrm{C}$ & $\begin{array}{l}\text { Komunikasi Tertulis/ Surat } \\
\text { Elektronik, Paket }\end{array}$ & Support \\
\hline Batam C & $500 \mathrm{Juta}-1 \mathrm{M}$ & $\mathrm{B} 2 \mathrm{C}$ & Paket & Support \\
\hline Batam D & $>1 \mathrm{M}-3 \mathrm{M}$ & B2B & Paket, Logistik & Turn around \\
\hline Semarang A & $>3 \mathrm{M}-5 \mathrm{M}$ & B2B & Paket & Turn Around \\
\hline Semarang B & $>1 \mathrm{M}-3 \mathrm{M}$ & $\mathrm{B} 2 \mathrm{C}$ & Paket & Support \\
\hline
\end{tabular}




\begin{tabular}{|c|c|c|c|c|}
\hline Perusahaan & $\begin{array}{c}\text { Biaya } \\
\text { operasional } \\
\text { per tahun }\end{array}$ & Karakteristik & Jenis Layanan & Mode \\
\hline Semarang C & $>1 \mathrm{M}-3 \mathrm{M}$ & $\mathrm{B} 2 \mathrm{~B}, \mathrm{~B} 2 \mathrm{C}$ & Paket & Support \\
\hline Semarang D & $>5 \mathrm{M}$ & $\mathrm{B} 2 \mathrm{~B}$ & Paket & Support. \\
\hline Jakarta A & $>3 \mathrm{M}-5 \mathrm{M}$ & $\mathrm{B} 2 \mathrm{~B}$ & $\begin{array}{l}\text { Komunikasi Tertulis/ Surat } \\
\text { Elektronik, Paket, Logistik }\end{array}$ & Strategic \\
\hline Jakarta B & $>1 \mathrm{M}-3 \mathrm{M}$ & $\mathrm{B} 2 \mathrm{~B}, \mathrm{~B} 2 \mathrm{C}$ & Paket & Factory \\
\hline Jakarta C & $>5 \mathrm{M}$ & $\mathrm{B} 2 \mathrm{~B}, \mathrm{~B} 2 \mathrm{C}$ & Paket & Factory \\
\hline Jakarta D & $>5 \mathrm{M}$ & $\mathrm{B} 2 \mathrm{~B}$ & $\begin{array}{l}\text { Komunikasi Tertulis/ Surat } \\
\text { Elektronik, Paket, Logistik }\end{array}$ & Factory \\
\hline Jakarta E & $>5 \mathrm{M}$ & $\mathrm{B} 2 \mathrm{~B}, \mathrm{~B} 2 \mathrm{C}$ & $\begin{array}{l}\text { Komunikasi Tertulis/ Surat } \\
\text { Elektronik, Paket, Logistik }\end{array}$ & Factory \\
\hline Jakarta F & $<500$ Juta & $\mathrm{B} 2 \mathrm{~B}$ & $\begin{array}{l}\text { Komunikasi Tertulis/ Surat } \\
\text { Elektronik, Paket, Logistik }\end{array}$ & Support \\
\hline Jakarta G & $>3 \mathrm{M}-5 \mathrm{M}$ & $\mathrm{B} 2 \mathrm{~B}$ & Paket, Logistik & Factory \\
\hline Mataram A & 500Juta - 1M & $\mathrm{B} 2 \mathrm{C}$ & $\begin{array}{l}\text { Paket, Logistik, Transaksi } \\
\text { Keuangan }\end{array}$ & Support \\
\hline Mataram B & 500Juta - 1M & B2B. B2C & $\begin{array}{l}\text { Komunikasi Tertulis/ Surat } \\
\text { Elektronik, Paket, Logistik }\end{array}$ & Support \\
\hline Mataram C & $>1 \mathrm{M}-3 \mathrm{M}$ & $\mathrm{B} 2 \mathrm{~B}, \mathrm{~B} 2 \mathrm{C}$ & Paket & Support \\
\hline Mataram D & 500Juta - 1M & $\mathrm{B} 2 \mathrm{C}, \mathrm{B} 2 \mathrm{~B}$ & Paket, Logistik & Support \\
\hline
\end{tabular}

Sumber: Hasil Penelitian, 2017

Karakteristik ringkas masing masing perusahaan penyelenggara pos dan logistik dijabarkan dalam lampiran (1). Berdasarkan hasil pemetaan dapat dilihat bahwa perusahaan dengan biaya operasional kurang dari $1 \mathrm{M}$ per tahunnya berada di mode support di mana TI hanya digunakan proses pendukung perusahaan dan apabila terjadi kegagalan sistem, maka seluruh prosesnya dapat digantikan secara manual dengan cepat. Perusahaan dengan biaya operasional kurang dari 1 Milyar pertahun umumnya perusahaan kecil dan menengah dengan keterbatasan modal untuk melakukan investasi TI sehingga investasi terhadap sistem informasi yang ada masih minim dan belum mendukung perusahaan untuk mendapatkan keuntungan strategis.
Penyedia layanan logistik kecil biasanya menawarkan layanan value added yang terbatas dan perangkat TIK memiliki potensi untuk memperbesar jangkauan layanan yang ditawarkan oleh penyedia layanan logistik kecil dengan memperbaiki kustomisasi layanan yang diberikan Hasil survei yang dilakukan oleh Evangelista dan Kilpala (2007) pada perusahaan penyedia logistik kecil menunjukkan potensi TI dapat diraih apabila perusahaan-perusahaan ini dapat mengatasi hambatan investasi teknologi (Evangelista \& Kilpala, 2007). Sedangkan perusahaan dengan biaya operasional lebih dari 1 Milyar sudah bergerak ke Turn Around, maupun sudah berada di mode Factory maupun Strategic. 


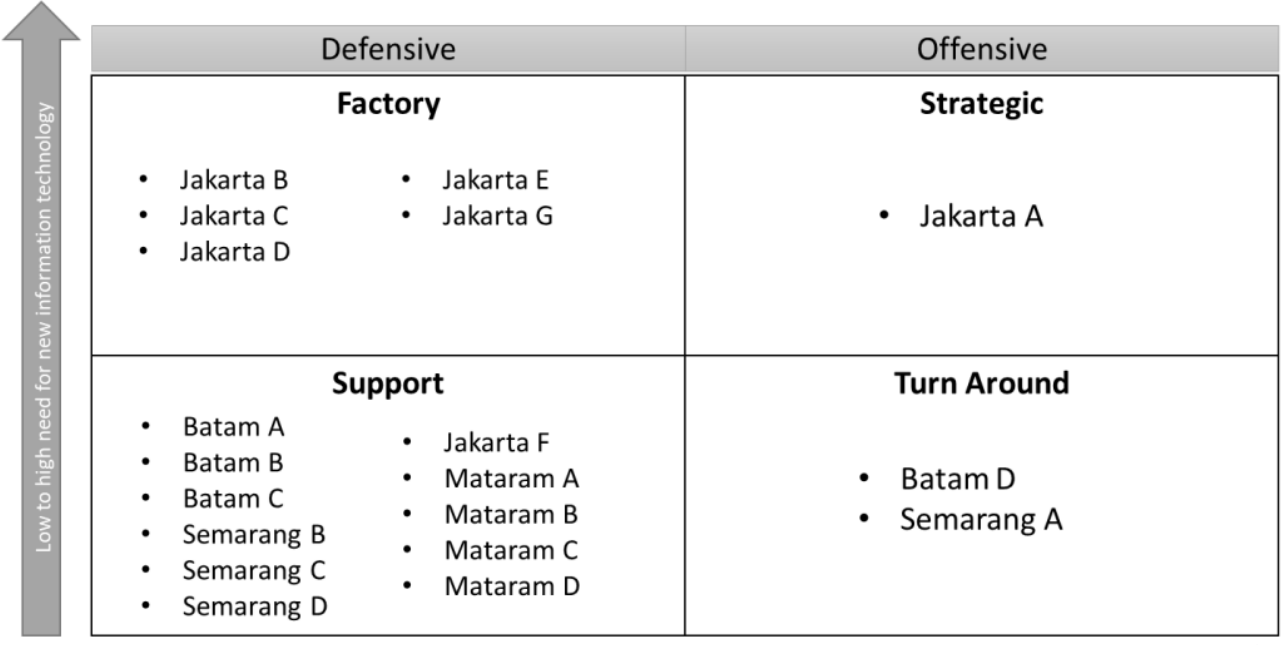

Low to high need for new information technology

Gambar 9. Pemetaan Perusahaan dalam IT Strategic Impact Grid Sumber: Hasil Penelitian, 2017

Berdasarkan hasil pemetaan dari platform e-commerce. Diharapkan melalui SI yang perusahaan penyelenggara pos dan logistik yang menjadi responden. Dapat dilihat bahwa mayoritas perusahaan di luar kota Jakarta berada di mode Support, di mana penggunaan TI hanya dilakukan untuk kegiatan pendukung bisnis di mana perusahaan tidak memiliki ketergantungan terhadap TI dan proses bisnis dapat dilakukan dengan sistem manual jika sistem yang dimiliki mengalami gangguan.

Perusahaan penyelenggara logistik tengah melakukan investasi TI, untuk bergerak dari mode Support menuju Factory ataupun Strategic dalam penelitian ini adalah Perusahaan Batam D dan Semarang A yang sama-sama memiliki model bisnis B2B (business to business). Kedua perusahaan melakukan investasi TI untuk mengubah proses bisnis utama menjadi online dengan melengkapi sistem tracking. Perusahaan Semarang A telah melakukan investasi dengan pelacakan armada pengiriman melalui GPS. Sistem yang dibangun bertujuan untuk meningkatkan layanan serta menurunkan gap dengan kompetitor yang sudah terlebih dahulu bekerjasama dengan dibangun akan memberikan transformasi proses dan layanan serta memberikan efisiensi biaya operasional dan meningkatkan daya saing.

Sedangkan perusahaan yang telah memanfaatkan TI dalam mode Factory seluruhnya berasal dari Jakarta dimana hampir seluruh aktivitas bisnis perusahaan dilakukan secara online, dan kegagalan sistem walaupun dalam waktu yang singkat akan berdampak pada proses bisnisnya. Beberapa perusahaan dalam mode Factory telah memiliki divisi khusus TI yang tugasnya untuk maintenance system sehingga meminimalisisr terjadinya kegagalan atau gangguan. Perusahaan dalam mode Factory merupakan perusahaan dengan strategi defensive dengan kebutuhan sistem informasi dengan reabilitas tinggi. Dapat dilihat pula bahwa perusahaan pos dan logistik yang berada di Jakarta memiliki kapasitas TI yang lebih baik.

Perusahaan penyelenggara pos dan logistik dalam penelitian ini yang sudah mengarah pada mode Strategic hanya 1 responden. Perusahaan tersebut selalu berinovasi dalam pengembangan 
sistem informasinya sehingga dapat memberikan daya saing yang tidak dimiliki kompetitornya. Perusahaan dalam mode ini merupakan perusahaan penyelenggara pos dan logistik baru namun didukung oleh kapasitas TI dari perusahaan induknya sehingga memilih strategi offensive TI karena mampu melakukan investasi terkait sistem baru yang bertujuan untuk meningkatkan performansi, layanan dan menurunkan biaya dibandingkan competitor. Core business perusahaan dilakukan secara online sehingga kegagalan sistem akan langsung berdampak pada kerugian, bahkan penurunan response times dari sistem juga akan berdampak merugikan baik dari internal maupun mitra perusahaan.

\section{Strategi Peningkatan Daya Saing TI}

Electronic commerce menuntut pendekatan tangkas, kecepatan tinggi, pendekatan logistik yang tangkas di mana pelanggan e-commerce adalah entitas tak dikenal yang memesan produk secara individual, menurut dorongan, demand musiman, harga dan kenyamanan (Bayles, 2002). Pos dan logistik berperan dalam distribusi barang dari toko online / marketplace ke pelanggan. Beberapa strategi peningkatan daya saing TI bagi perusahaan logistic dapat dibahas dibawah ini.

\section{Optimasi Potensi Ekonomi}

Untuk mengoptimalkan potensi ekonomi berbasis e-commerce, pemerintah telah mengeluarkan kebijakan ekonomi untuk mendorong percepatan dan pengembangan sistem perdagangan nasional berbasis elektronik termasuk di dalamnya adalah percepatan logistik. Beberapa program terkait optimasi potensi ekonomi di antaranya pelaksanaan alih daya fasilitas Logistik $E$ -
Commerce untuk Usaha Mikro, Kecil, dan Menengah dan Peningkatan kapasitas penyedia jasa lokal/nasional untuk memenuhi kebutuhan pengiriman di seluruh indonesia.

Sebagai bagian dari keseluruhan sistem distribusi barang, e-commerce dapat berkontribusi terhadap dampak yang saling berkait, untuk pengiriman yang lebih jauh, seringkali frekuensi pengiriman yang lebih tinggi karena peningkatan demand pengiriman darat, jalur transhipment baru serta pengiriman udara yang lebih sering (Hesse, 2002). Untuk mencapai peningkatan kapasitas penyedia jasa lokal/nasional yang berdaya saing dalam industry e-commerce, kemampuan perusahaan untuk beradaptasi dan mengadopsi teknologi informasi menjadi kebutuhan yang utama. e-Commerce dan TI adalah komponen yang saling berkaitan bagi perubahan dalam distribusi (Hesse, 2002). Oleh karenanya dalam implementasi strategi peningkatan kapasitas penyedia jasa pos dan logistik lokal/nasional perlu memperhatikan pola dampak teknologi informasi pada masing-masing perusahaan.

\section{Investasi Teknologi Informasi dan Kemampuan e-}

\section{leadership}

Berdasar hasil penelitian yang dilakukan, penggunaan teknologi informasi pada perusahaan pos dan logistik sebagian besar masih berada dalam mode support di mana penggunaan TI masih sebatas untuk mendukung proses bisnis perusahaan dan belum dimanfaatkan untuk mendapatkan keunggulan strategis dari perusahaan. Dari hasil wawancara disimpulkan implementasi teknologi dalam perusahaan selain terkait dengan kemampuan investasi perusahaan, tetapi sangat erat kaitannya dengan bagaimana e-leadership dari pimpinan perusahaan. Avolio dan Kahai (2003) dalam 
(Avolio, Sosik, Kahai, \& Baker, 2014) menyatakan bahwa teknologi mempengaruhi kepemimpinan, memandang e-leadership sebagai "perubahan mendasar dalam cara pemimpin dan pengikut terkait satu sama lain dalam organisasi dan antar organisasi. TIK, dan e-leadership bertujuan untuk menciptakan dan mendistribusikan visi organisasi, menyatukan perusahaan atau individu bersama, serta mengarahkan dan mengawasi pelaksanaan rencana tersebut seperti kepemimpinan tatap muka tradisional, kepemimpinan juga bisa memberi inspirasi melalui komunikasi melalui e-mail atau sarana elektronik lainnya (Dasgupta, 2011)

Salah satu narasumber dari perusahaan pos dan logistik besar saat ini masih menjalankan proses bisnis secara tradisional tanpa implementasi TI, dikarenakan belum ada kebutuhan dari pimpinan tertinggi perusahaan untuk melakukan implementasi TI. Akan tetapi di era e-commerce, teknologi informasi terutama internet merupakan infrastruktur utama yang sangat dibutuhkan. Perusahaan yang masih mempertahankan pola tradisional umumnya perusahaan keluarga. Beberapa perusahaan yang dimpimpin oleh generasi penerusnya, telah mulai menyadari pentingnya teknologi, bagi kelangsungan perusahaan. (Dasgupta, 2011) menyatakan kepemimpinan dan teknologi, memiliki hubungan rekursif, masing-masing mempengaruhi dan pada saat bersamaan dipengaruhi oleh yang lain; masingmasing berubah dan ditransformasikan oleh yang lain.

\section{Peningkatan Kapasitas Sumber Daya Manusia}

Dalam pelaksanaan strategi peningkatan kapasitas penyedia jasa lokal/nasional untuk memenuhi kebutuhan pengiriman adalah dengan melakukan training tekait e-leadership sehingga para pemimpin perusahaan pos logistik utamanya perusahaan UMKM dapat melakukan transformasi untuk mendukung percepatan dan pengembangan ecommerce, di mana idealnya proses bisnis utama perusahaan telah online dan sistem informasi yang diterapkan dapat meningkatkan strategi diferensiasi ataupun pengurangan biaya secara signifikan.

\section{Keikutsertaan dalam Asosiasi dan lembaga terkait}

Investasi terhadap teknologi informasi bagi perusahaan UMKM menjadi salah satu kendala dikarenakan keterbatasan modal. Dalam hal ini pemerintah dalam Perpres no 74 tahun 2017 telah menyatakan bahwa untuk meningkatkan kapasitas penyedia jasa logistik lokal/nasional dengan pembinaan dan pemberian akses permodalan. Selain itu, berdasarkan wawancara dengan narasumber dari Asosiasi Perusahaan Jasa Pengiriman Ekspres Pos dan Logistik Indonesia (Asperindo), telah mengembangkan program Asperindo Logistic Integration Solution (ALIS) untuk membantu para pelaku Usaha Mikro, Kecil, dan Menengah (UMKM) yang selama ini mengalami kendala pemasaran produk dan proses distribusi. ALIS merupakan platform sistem operasi virtual yang berfungsi sebagai portal interkoneksi anggota Asperindo, sehingga mitra dengan jangkauan terbatas dapat bekerjasama dengan mitra lain yang berjangkauan lebih luas dalam bisnis kerjasama untuk forwarder. Selain itu tersedia Courier Express System yang menyediakan sistem pencatat operasional, termasuk penjualan, sorting, inbound, outbond, pengiriman, dan tracking AWB document yang menyediakan berbagai report untuk memudahkan pemantauan data keuangan dan operasional. Karenanya perusahaan penyelenggara pos dan logistik didorong menjadi anggota asosiasi untuk mendapatkan fasilitas dan kemudahan berjaringan mitra. 
Integrasi system, konsolidasi kebijakan dengan berbagai sektor

Adapun strategi lain bagi peningkatan kapasitas TI pada internal perusahaan pos dan logitik untuk dapat berkontribusi pada potensi pasar e-commerce di Indonesia yaitu dengan membangun kerja sama serta integrasi platform e-commerce dengan sistem internal, meningkatkan kapasitas TI melalui training atau pelatihan dibidang TIK, serta meningkatkan investasi di bidang TI baik di sektor infrastruktur maupun organisasi.

Diharapkan melalui inisiatif dari pemerintah dan asosiasi serta arah kebijakan internal perusahaan untuk meningkatkan kapasitas TI sehingga pemanfaatan TI tidak hanya dalam mode support, tetapi dapat beralih ke factory bahkan strategic sehingga perusahaan dapat berdaya saing untuk mengambil peran dalam potensi transaksi e-commerce di Indonesia.

\section{Potensi dan Editing Strategi}

Potensi ekonomi dari perdagangan elektronik (e-commerce) berdampak langsung pada pertumbuhan arus distribusi barang. Perkembangan teknologi informasi dan internet harus dipandang sebagai media yang dapat menjadi katalis transformasi proses bisnis di bidang penyelenggaraan pos dan logistik. Perusahaan penyelenggara pos dan logistik harus mampu beradaptasi dari paradigma bisnis yang konvensional menjadi perusahaan yang inovatif dengan memanfaatkan platform e-commerce untuk memperluas jangkauan bisnis.

Dalam era trasnformasi ekonomi digital, perusahaan pos dan logistik yang memiliki kemampuan beradaptasi dengan teknologi akan menjadi perusahaan yang memiliki keunggulan strategis. Penelitian ini berupaya memberikan gambaran peran TI dalam perusahaan penyelenggara pos dan logistik. Berdasarkan hasil penelitian, melalui pemetaan IT Strategic Impact Grid perusahaan penyelenggara pos dan logistik yang menjadi responden mayoritas masih berada pada mode Support yang paling tidak bergantung pada TI. Perusahaan dengan mode Support, TI hanya digunakan untuk mendukung proses penunjang (keuangan, administrasi, dsb) dan belum menggunakan TIK untuk menunjang proses bisnis utamanya. Dalam transaksi e-commerce sangat terkait dengan teknologi informasi dan internet sehingga perusahaan pos dan logistik yang masih minim adopsi TI, masih mengandalkan pola kemitraan konvensional akan ketinggalan dengan perusahaan lain yang mampu mengimplementasikan TI untuk mendukung strategi perusahaan.

Perusahaan penyelenggara pos dengan mode Factory telah memanfaatkan TI untuk menunjang proses bisnis utamanya dan hampir seluruh proses bisnis utamanya telah online. Perusahaan dalam mode ini telah memiliki aplikasi yang terintegrasi dengan mitra dan pelanggan sehingga proses bisnis inti dari perusahaan penyelenggara pos telah dilakukan melalui aplikasi, seperti invoicing, tracking, warehouse management, stock management hingga penggunaan data transaksi untuk mengambil keputusan. Karenanya aplikasi dan sistem informasi menjadi sangat vital bagi perusahaan, kerusakan sistem akan berdampak bagi seluruh perusahaan. Perusahaan dalam mode ini merupakan perusahaan yang siap mendapatkan keuntungan optimal dengan adanya e-commerce.

Perusahaan penyelenggara pos dalam mode Strategic membutuhkan dukungan sistem informasi dan aplikasi yang handal serta inovasi TI yang 
didukung dengan SDM TIK dengan kompetensi yang tinggi. TI bukan hanya digunakan untuk mendukung penuh kegiatan logistik, tetapi juga telah menjadi keunggulan perusahaan dibanding perusahaan saingan, Melalui aplikasi yang dimiliki perusahaan, maka profit dan efisiensi perusahaan akan meningkat, dan sebaliknya kerusakan sistem akan langsung berdampak pada kerugian bagi perusahaan logitik.

Untuk meningkatkan kapasitas TI bagi perusahaan, diperlukan adanya e-leadership bagi para pemimpin perusahaan pos dan logistik, utamanya yang berskala kecil dan menengah yang belum memahami pentingnya transformasi teknologi untuk peningkatan performansi perusahaan maupun efisiensi biaya. Kurangnya eleadership dan keterbatasan investasi TI merupakan hambatan utama bagi perusahaan pos dan logistik untuk dapat menginplementasikan TI bagi proses bisnis perusahaan. Pemanfaatan plaform sistem operasi virtual bersama untuk mengatasi hambatan investasi teknologi, serta peningkatan kapasitas SDM TIK diperlukan untuk peningkatan kapasitas TI perusahaan. Diharapkan perusahaan pos dan logistik di Indonesia dapat memanfaatkan TI bukan hanya sebagai pendukung, tetapi mendorong peran TI ke mode factory dengan implementasi sistem teknologi operasi yang hemat biaya, efisien, efektif, aman dan handal (disebut sebagai "defensif" TI), bahkan kearah Strategis untuk meningkatkan keunggulan kompetitif melalui sistem yang memberikan layanan dan produk bernilai tambah baru atau responsif tinggi kepada pelanggan ("ofensif" TI).

\section{UCAPAN TERIMA KASIH}

Kami mengucapkan terima kasih kepada Puslitbang SDPPPI yang telah membantu dan memfasilitasi pelaksanaan penelitian ini serta Asperindo yang membantu dalam penulisan karya tulis ilmiah ini.

\section{DAFTAR PUSTAKA}

Avolio, B. J., Sosik, J. J., Kahai, S. S., \& Baker, B. (2014). E-leadership: Re-examining transformations in leadership source and transmission. Leadership Quarterly, 25(1), 105-131. https://doi.org/10.1016/j.leaqua.2013.11.003

Bayles, D. L. (2002). E-Logistics \& E-Fulfillment: Beyond the "Buy" Button. UNCTAD Workshop, 1-12.

Dasgupta, P. (2011). Literature Review: eLeadership. Emerging Leadership Journeys, 4(1), 1-36. https://doi.org/10.15213/redes.n10.p309

Espinosa, C. M., \& Morales, F. X. M. (2015). Information and Communication Technology in Logistic Processes of The Companies. Universitat Jaume i.

Evangelista, P., \& Kilpala, H. (2007). The perception on ICT use among small logistics service providers: a comparison between Northern and Southern Europe, 35, 81-98.

Evangelista, P., \& Sweeney, E. (2009). The role of information and communication technology in small Italian logistics enterprises. International Journal of Business and Systems Research, 3(1), https://doi.org/10.1504/IJBSR.2009.023504

Hesse, M. (2002). Shipping news: The implications of electronic commerce for logistics and freight transport. Resources, Conservation and Recycling, 36(3), 211-240. https://doi.org/10.1016/S09213449(02)00083-6

Hong-Ying, S. (2009). Application of Barcode technology in Logistics and Warehouse Management.

Ilich, L. (2017). IMPACT OF ICT ON LABOR MARKET DEVELOPMENT: MAIN TRENDS AND PROSPECTIVES. Open educational eenvironment of modern university (Vol. 3).

Jafari, S. M. B. (2014). Strategic cost-cutting in information technology: Toward a framework 
for enhancing the business value of IT. Iranian Journal of Management Studies (IJMS), 7(1), 21-39.

Logistic Summit 2015. (2015).

Luisa dos Santos Vieira, C., Sérgio Coelho, A., \& Mendes Luna, M. M. (2013). ICT implementation process model for logistics service providers. Industrial Management \& Data Systems, 113(4), 484-505. https://doi.org/10.1108/02635571311322757

Mulyadi, D. (2011). 140-436-1-Pb275-282 (2). Jurnal Riset Industri. Retrieved from http://www.kemenperin.go.id/download/4721/ Pengembangan-Sistem-Logistik-yang-Efisiendan-Efektif-degan-Pendekatan-Supply-ChainManagement

Naicker, V., \& Pillay, R. (2010). Electronic Data Interchange in Developing Countries: Lessons from South Africa.

Nolan, R., \& McFarlan, F. W. (2005). Information Technology and the Board of Directors
Information Technology and the Board of Directors. Harvard Business Review.

Pane, E. S. (2016). Pemanfaatan teknologi informasi dan komunikasi (tik) untuk mereduksi biaya logistik pada transportasi multimoda. Jurnal Masyarakat Telematika Dan Informasi, Volume: 7, 35-48.

Widyarto, A. (2012). Peran Supply Chain Management Dalam Sistem Produksi Dan Operasi Perusahaan. BENEFIT Jurnal Manajemen Dan Bisnis, 16, 91-98. Retrieved from

http://journals.ums.ac.id/index.php/benefit/arti cle/view/1362

World Development Report 2016 "Digital Dividends." (2016).

Zaroni. (2015). Logistik E-Commerce. Supply Chain Indonesia. Retrieved from http://supplychainindonesia.com/new/wpcontent/files/Logistik_E-Commerce1.pdf. 